\title{
Customer Relationship Management and Online Customer's Brand Loyalty
}

\author{
Yufan Yu \\ School of Economics and Management \\ East China JiaoTong University \\ Nanchang, China \\ yuyufan1314@163.com
}

\begin{abstract}
With the development of web economy, brand competition is very serious. Branding on the Web will be built through experience. Competition is not about product or service, but about customer relationship. More and more organizations realize that brand loyalty is a valuable variable, and the efficient customer relationship management can improve brand competitiveness. Customer relationship management (CRM) is committed to the following things: changes of the marketing drive, corporations' inside needs and the information technology development. So the paper discussed the definition of CRM, and then introduced the relative theories which prove building brand loyalty through CRM is reasonable and feasible. Finally on the basis of these, the paper put forward the principle and implementation way of building brand loyalty though CRM.
\end{abstract}

Keywords- customer relationship management system; brand value; customer satisfaction; brand loyalty program

\section{INTRODUCTION}

As a result of internet could provide lower searching cost for consumer (Strader and Shaw1997), it is easier for consumer to compare the price while shopping through the internet (Horng-Der Leu et al.2011). So, on-line marketing must maintain customer relationship. Brand Loyalty is the important resource of brand capital. In the view of the depth and breadth of brand, the establishment and development of brand loyalty means deep interaction with customers. The core of brand strategy must focus on the relationships between brand and customers, namely cultivating customer loyalty. The relationship between brand and customers grows out of nothing and expands from small to large. Highly satisfying customer demand can result in repeat buying, and finally develops stable customer relationship. In order to do this, maintaining good interaction with customers is essential. According to marketing practices, satisfied customers may not be loyal customers. But it is undeniable that the basis of loyalty is satisfaction. Our question is to find out the efficient way of making satisfied customer loyalty. Therefore, the paper discussed the relationship between CRM and brand loyalty.

Although both the academic and business circles think that efficient customer relationship is very important, literatures about how to build efficient CRM is not enough. A few corporations regard CRM as only software investment, or just effective communication with customers. But in fact, CRM is both a management philosophy and an automatic management system. The point is to focus on customers and cultivate good customer relationship. And the paper hopes to find out a effective method to manage customer relationship.

\section{CRM TOOLS FOR BRAND LOYALTY}

Customer Relationship Marketing (CRM) is a business process in which client relationships, customer loyalty and brand value are built through marketing strategies and activities

(Peppers \& Rogers1993). CRM's core strength is an ability to glean insights from customer feedback to create enhanced, solid and focused marketing and brand awareness. Customer relationship can be built on, reinforced, and improved through a number of CRM programs, including customization, community building, customer service requirements, rewards programs, and loyalty programs (Winer2001). Perhaps, one of the most powerful programs in CRM is the loyalty program, which is designed to increase brand loyalty and customer satisfaction. Loyalty program which may be implemented by various ways makes it possible for the firm to create a mutually beneficial relationship and the ultimate goal for each party to receive a positive benefit (Brown2000).

Yet true rand loyalty is composed of two components: attitudes loyalty and behavioral loyalty. Attitude loyalty is created when customers hold positive, strong beliefs about some brand. And once customers have emotional commitment to the brand, behavioral loyalty often follows in the form of repeat purchases or frequent store visits (Reinartz2006). Hence the firm must design loyalty programs to enhance both attitude loyalty and behavioral loyalty.

When designing a loyalty program, the reward structure accounts for the most defining characteristic. The reward structure is the most alluring component of the loyalty program; consumers are primarily attracted to loyalty programs because of the rewards and benefits available to them (MimouniChaabane \& Volle 2010). One hand, loyalty programs can offer tangible and financial benefits. Meanwhile psychological benefits are important rewards to customers. Customers may also receive symbolic benefits through self expression, recognition, and approval. These benefits are not related to tangible characteristics or to products; they pertain specifically to an individual's self-esteem and how they feel they are perceived by the world (Mimouni-Chaabane \& Volle 2010).Of course, the effect of the loyalty program depends on whether customers adopt the program and continually use the CRM tools provided to them or not (Mauri2003). 
Therefore, customer relationship management software is to help with dealing with customer issues in order to offer better service to them. CRM offers a unified platform where you store a trove of information on your customers. This information can be extracted and analyzed to build a business strategy that will ensure long term business growth. Customer management systems essentially collect data on customers. The information collected by CRM can be applied to both B2B and B2C business environments in designing customer driven business model. In detail, the data gathered is then fed to the sales, marketing and customer service department in order to achieve higher sales and customer retention rate. But all these efforts aren't visible to customers. In order to achieve higher customer orientation marketers must look at CRM system from the view point of a customer, considering the information in the new light of improving customer retention and instilling brand loyalty. This insight then can be applied to in building personalized relationship with customers.

\section{THE PRINCIPLE OF BUILDING BRAND LOYALTY THOUGH CRM}

In order to understand how CRM affects Brand Loyalty, it is necessary to understand how brand loyalty develops. Prospect theory, the satisfaction theory, and learning theory can be applied to explain how Brand Loyalty developed. In detail, firstly customers select to buy some good basing on information indexing and buying decision. When the utility of the good exceeds customer's expectation, the customer will be pleased to the product or service. The satisfaction becomes a positive reinforcement which will influence customer's attitudes to the brand and next buying. After several reinforcements, customer will get into the habit of buying a particular brand and finally develop brand loyalty to the brand. Namely the influencing factors of brand loyalty may be cognition, attitude and behavior.

Customer value is not determined by the enterprises, but perceived by customers, that is, the so-called customer perceived value. Customer value is determined by a number of factors including market share, competition, material costs, product identity and the customer's perceived value of the product. Customer satisfaction depends on so much on managing themselves' expectations. In on-line marketing, customer satisfaction is an important index. More companies try their best to satisfy customer in order to maintain long-term relationship. And we know that satisfied customer will lead to loyal customer. Thus, in on line marketing, we need catching customer's attention in order to further build the long term loyalty.

The CRM software help you track how a contact has been managed. Winning customer loyalty is all about creating favorable images of yours among customers and only then you can expect them to talk about you. You cannot win customer loyalty by providing poor and untimely services experience. Since the software integrates all aspects of customer management, namely- sales, marketing and services, it let you track the interaction you had with a particular contact. With the help of the information you can even turn negative Words of Mouth into a positive one.

\section{MANAGING CRM PROCESS}

CRM is an essential business strategy. It is about service. No business can go unaffected by losing its most loyal customers. Once the CRM components are determined by the corporation, the next step is to actively manage the process through a serial of works such as role specification, employee training, effective communication, and performance evaluation. Role specification is necessary in managing the relationships of $\mathrm{CRM}$, and its main goal is to define the responsibilities and duties of the relationship partners such as the firm, the employees, and the customers (Heide1994). After defining roles specification, the employees must be adequately trained to implement the CRM programs. Successfully executing effective CRM demands employees to hold strong sales and communication skills. Meanwhile employees should be trained to provide exceptional on-line service (Formant 2000). Employees are direct to contact with customers and what they do can enhance or weaken customer-company relationships, sometimes they must make decisions regarding customer service. Therefore employees need understanding how to apply the customer information located in the databases efficiently and effectively into build relationships and increase customer satisfaction. That is to say, employees are the core of CRM strategy, companies should focus on employee satisfaction and offer employee motivation in the form of rewards or incentives (Parvatiyar \& Sheth 2001), which is call Internal Marketing (IM). According to IM theory, Customer satisfaction and employee loyalty and are positively related to each other.In order to carry out any successful service, the company should accurately communicate with its internal audience (the employees) as well as its external audience (the customers).

CRM requires sufficient communication because communication is essential to building relationships with the customers. When training and enforcing guidelines and policies CEO and customer relationship managers must explain the CRM goals of the company and how the CRM programs will be implemented to the others in the company. Meanwhile target customers must be informed about the CRM programs in order to encourage behavioral loyalty such as repeat purchases, premium consumption, good WOM and so on. The firm must perfect the communication channels between the firm and the customers to ensure that information is being accurately shared.

The final step of CRM is to evaluate results. Employees strive to build and maintain customer relationships in order to increase long-term profits. If the CRM programs are unsuccessful and the firm does not get a moderate return on investment (ROI), the CRM process should be modified immediately. Since CRM programs involve many aspects, it is often difficult to measure its performance. Or it is hard to select a reasonable indicator to evaluate CRM. Although academy believes that there is no technology or method to measures the success of CRM completely accurately, practical operation must be careful. The CRM process should be evaluated using a set of unique performance metrics that reflect the core concepts of a firm's relationship marketing (Roberts, Liu, \& Hazard 2005).The customer perspective includes customer loyalty measured by customer satisfaction and customer value measured by surveys and number of customer complaints. The process perspective is another component of the CRM 
scorecard and includes evaluating the overall success of the business strategy by measuring customer acquisition, retention, and expansion.

\section{BUILDING ON LINE CUSTOMER'S BRAND LOYALTY}

On-line marketing has great advantages such as no real limit on advertising space, private and swift shopping, fast information access and retrieval and so on (Kotler2000). But marketers also must confront tremendous risk. For example, on the web, one can freely throw brand preference, a long-term relationship and customer loyalty out the window (Hacker2000). Besides each organization has a unique culture and unique business processes. Therefore it is important to focus on CRM solution, and try to find out its advantages to achieve the success.

The first step is on-line Customer Recognition. Customer recognition is of great importance to the implementation of CRM, and the selection of customer features is an important problem in customer recognition. William Band(1998) pointed that not all customers are worth. The core of CRM is to maintain regular customers and no to attract new customers. The theory of commerce circle, Lai-li method and 20-vs-80 method provides the evidence to construct the effective marketing channel. Finding out and locking at $20 \%$ regular customers is the key of CRM because they will become the loyal customers.

Next, marketers must understand customers through databases. Database includes not only information, and effective data integration. Online Customer Service is to connect with your customers to sell more. Likewise companies with a genuine need to reach online customers find their mass mailings getting lost in spam folders. So it is important for database to real-time update customer information.

The third step is to analyze database. Marketers must find out the regulation by processing a great number of scattered data with computer. The reason behind is to find customers' potential demand or potential discontent. These findings will come out only after analyzing data through CRM system and forming readable charts. On the bases of above, employees can make the right decision timely satisfying customer's demand and removing complaints. The practice indicates that clearing up the customers' complaining psychology is the effective way to raise the customers' satisfaction degree and cultivate loyal customers.

The forth step is meeting customization requirement. CRM aims at building deep and personal relationship with customers. Customer demand is varied. CRM can tailor-made rather than mass production and meet customer demand to the max. Multiple practices are necessary to improving customer delivered value. Philip Kotler put forward the theory, "Customer Transfer Value", which is the theoretical basis of maintaining the customers effectively. In such sense, faced to the fierce competition, enterprises should create and deliver more value for consumers if they want to satisfy consumers and win over competitors. The amount of the Customer Transfer Value decides the depth of the customer satisfaction and also the degrees of the customer loyalty.
Finally, continuing communication builds long-term relationship and chive brand loyalty. Customer satisfaction is not necessary, but undoubtedly is important factor to brand loyalty. CRM aims to reach out to customers to meet their individual needs and exceed their expectations. Firms implement relationship programs, such as community-building websites and loyalty card programs, to develop a trusting relationship among consumers to gain their confidence and increase repeat purchases. Customers may also receive symbolic benefits through self expression, recognition, and approval. These benefits are not related to tangible characteristics or to products; they pertain specifically to an individual's self-esteem and how they feel they are perceived by the world.

\section{SUMMARY}

Efficient CRM will help to build brand loyalty. Yet brand loyalty is a multidimensional concept. CRM help building brand loyalty mostly acting on customer value and customer satisfaction, both of which are the important factors forming brand loyalty. In CRM, the key is maintaining the regular customers, which has profound implications for branding. So, companies should apply CRM system into successfully implement brand loyalty program.

\section{Acknowledgment}

This paper is with the National Natural Sciences Fund Item "Entrepreneur Brand Attachment: Measurement Dimension, Influencing Factors and Mechanism Research " (Grant Number: 71362003) for the subject source, and has got subsidizing of it.

\section{REFERENCES}

[1] Gummerus, J. Liljander, V .Weman, E. and Pihlstro “" m, M.(2012) 'Customer engagement in aFacebook brand community' Management Research Review, 35 ,(9)pp. 857-877.

[2] Lemke, F. Moira, C. \& Hugh, W. (2011) 'Customer Experience Quality: An Exploration in Business and Consumer Contexts using Repertory Grid Technique', Journal of the Academy of Marketing Science, 39, (6) pp.846-69.

[3] Aîda Mimouni-Chaabane \& Pierre Volle (2010), Perceives benefits of loyalty programs: Scale development and implications for relational strategies [J], Journal of Business Research, 63 (1) :32-37.

[4] Roberst, M. L., Liu, R.R., Hazard, K. (2005), Technology and organizational alignment: key components of CRM success[J], Database Marketing \& Customer Strategy Management, 12(4):315- 326.

[5] Winer, R.(2001), A Framework for Customer Relationship Management [J].California Management Review, 43(4) : 89-105.

[6] Atul Parvatiyar \& Jagdish N. Sheth, Customer Relationshio Management: Emerging Practice, Process, and Discipline[J]. Journal of Economic and Social Research 3(2) 2001, 2002 Preliminary Issue, 1-34

[7] M. Young, The Technical Writer's Handbook. Mill Valley, CA: University Science, 1989.

[8] Brown, S. A.(2000), Customer Relationship Management: A Strategic Imperative in the World of E-Business[M], Canada: John Wiley \& Sons.

[9] Brown, S. A.(2000), Customer Relationship Management: A Strategic Imperative in the World of E-Business[M], Canada: John Wiley \& Sons.

[10] Parvatiyar, A. \& Sheth, J. (2001), Customer Relationship Management: Emerging Practice, Process, and Discipline [J]. Journal of Economic and Social Research, 3(2): 1-34. 